\title{
Evaluating the effect of chromosomal context on zinc finger nuclease efficiency
}

\author{
Scott Bahr*, Laura Cortner, Sara Ladley, Trissa Borgschulte \\ From 23rd European Society for Animal Cell Technology (ESACT) Meeting: Better Cells for Better Health \\ Lille, France. 23-26 June 2013
}

\begin{abstract}
Introduction
Zinc Finger Nuclease (ZFN) technology has provided researchers with a tool for integrating exogenous sequences into most cell lines or genomes in a precise manner. Using current methods, the efficiency of targeted integration (TI) into the host genome is generally low and is highly dependent on the ZFN activity at the genomic locus of interest. It is unknown if the ZFN binding and cutting efficiency is more dependent on the nucleotide recognition sequence or the chromosomal context in which the sequence is located.

We have taken a highly efficient ZFN pair (hAAVS1) from human studies and introduced the exogenous DNA sequence into the Chinese Hamster Ovary $(\mathrm{CHO})$ genome in an attempt to improve the efficiency of targeted integration. A "Landing Pad" comprised of human AAVS1 sequence has been integrated into the $\mathrm{CHO}$ genome at 3 separate loci to determine if the ZFN's will work across species and if the cutting efficiency is affected by chromosomal context. The results of this study will help us to improve the overall efficiency of TI by using Landing Pads, particularly for genomic targets in which suitable ZFN's may not be available.
\end{abstract}

\section{Methods}

3 CHO Loci were chosen for this study based on previous gene expression studies. Rosa26 and Neu3 show consistent but low levels of expression while Site \#1 appears to have no known coding sequence. Additionally, Rosa26 and Site\#1 were chosen as potential safe harbor sites in $\mathrm{CHO}$. The ZFN cutting efficiency at the endogenous $\mathrm{CHO}$ loci Rosa26, Site \#1 and Neu3 are approximately $15 \%, 30 \%$ and $40 \%$ respectively. Based on other studies the cutting efficiency of human AAVS1 ZFN's was as high as $50 \%$ depending on the human cell line used. A plasmid donor carrying the hAAVS1 ZFN recognition sequence Landing Pad was introduced into CHO Rosa26, Site \#1, and Neu3 via targeted integration (Figure 1).

\section{Results}

Clones carrying the exogenous hAAVS1 Landing Pads at Rosa26, Site \#1 and Neu3 were transfected with hAAVS1 ZFN's and the cutting efficiency was measured. We found that the human AAVS1 ZFN's were able to successfully cut at their recognition sequence in the Landing Pad at all $3 \mathrm{CHO}$ loci to varying degrees (Table 1). ZFN efficiency at each loci was measured by Cel1 Assay or direct sequencing of Indels in PCR amplicons. We see successful ZFN activity at all 3 loci but with varying efficiency. **The Landing Pad integration at Neu3 locus caused phenotypic changes in the cell growth and viability following transfection which may explain low ZFN activity.

Table 1 Comparing ZFN activity in CHO before and after Landing Pad Integration

\begin{tabular}{ccc}
\hline $\begin{array}{c}\text { CHO } \\
\text { Site }\end{array}$ & $\begin{array}{c}\text { ZFN Activity at Endogenous } \\
\text { CHO Locus }\end{array}$ & $\begin{array}{c}\text { ZFN Activity at Integrated } \\
\text { Landing Pad }\end{array}$ \\
\hline $\begin{array}{c}\text { Rosa } \\
\mathbf{2 6}\end{array}$ & $16 \%$ & $18 \%$ \\
\hline $\begin{array}{c}\text { Site } \\
\mathbf{1 1}\end{array}$ & $31 \%$ & $51 \%$ \\
\hline Neu3 & $41 \%$ & $16 \%^{* *}$ \\
\hline
\end{tabular}

\footnotetext{
* Correspondence: scott.bahr@sial.com

$\mathrm{CHOZN}^{\mathbb{R} \otimes}$ Platform Development Team, SAFC/Sigma-Aldrich, St Louis, MO 63103, USA
} 


\section{Exogenous Landing Pad Plasmid Donor}

\section{Homology Arm hAAVS1 \\ Homology Arm}

\section{Landing Pad}

\section{Endogenous $\mathrm{CHO}$ Genomic Loci}

\section{ZFN Recognition Sequence}

\section{Co-Transfection:}

- ZFN's to Genomic Loci

- Landing Pad Donor
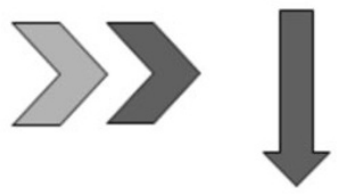

\section{Integration of hAAVS1 \\ Landing Pad into $\mathrm{CHO}$ genome}

Figure 1 Schematic of ZFN mediated Integration of the hAAVS1 Landing Pad into CHO

\section{Conclusions}

These results indicate that the chromosomal context of the ZFN recognition sequence has an effect on cutting efficiency. This study shows that TI can be performed with Landing Pads across species with high efficiency and provide researchers with additional tools for cell line engineering. Further development of Landing Pads could create highly engineered and multi-functional platforms that would facilitate more efficient and more tailored $\mathrm{CHO}$ cell modifications.

Published: 4 December 2013

doi:10.1186/1753-6561-7-S6-P3

Cite this article as: Bahr et al.: Evaluating the effect of chromosomal

context on zinc finger nuclease efficiency. BMC Proceedings 2013 7(Suppl 6):P3.
Submit your next manuscript to BioMed Central and take full advantage of:

- Convenient online submission

- Thorough peer review

- No space constraints or color figure charges

- Immediate publication on acceptance

- Inclusion in PubMed, CAS, Scopus and Google Scholar

- Research which is freely available for redistribution 